\title{
A ladder of lies: the adaptive advantages of deception
}

\author{
Lora E Adair ${ }^{*}$ and Haley M Dillon
}

The Folly of Fools: The Logic of Deceit and Self-Deception in Human Life, by Robert Trivers. Philadelphia, PA: Basic Books, 2011.

'The ultimate effect of shielding men from the effects of their folly is to fill the world with fools'. - Herbert Spencer

Largely through historical examples and personal anecdotes, Robert Trivers builds the foundation for an evolutionary theory of self-deception and deceit in his recent book, The Folly of Fools: The Logic of Deceit and Self-Deception in Human Life. Beginning with the evolutionary roots and logic of our unrivaled ability to hide the truth from ourselves and others, Trivers then explores phylogenetic, psychological, anthropological, and historical examples of deception, its consequences, and its propagation.

Perhaps the most thought-provoking aspect of The Folly of Fools is Trivers visiting, and revisiting of the (seemingly) incompatible notions that: (1) of the most complex creatures that have ever evolved, we have a sensory system that provides us with an incredibly rich image of the world around us; yet (2) our brains swiftly bend, distort, or ignore this information. In other words, why, at the expense of valuable energetic resources, has evolution favored such sensitive truth-detecting and truth-dispensing processes?

It is worth noting that this stark truth/lie dichotomy is likely a bit of an exaggeration; for example, visual perception does not have to wait for processing in visual areas of the brain to be distorted. The bending and aggregating of visual information begins as early in sensory processing as retinal ganglion cells. This relative lack of 'truth' in our sensory experience is, later in the text, addressed by Trivers: 'At every single stage - from its biased arrival, to its biased encoding, to organizing it around false logic, to misremembering and then misrepresenting it to others, the mind continually acts to distort information flow...' (p. 139).

\footnotetext{
* Correspondence: lorap@ksu.edu

Kansas State University, Manhattan, KS, USA
}

To marry these two general findings - that we are sensitive and attentive to information in our environment and that we are adept self-deceivers - Trivers proposes, 'we deceive ourselves the better to deceive others' (p. 3). It becomes clear that Trivers favors, as he explains it, this 'offensive' view of self-deception, compared to a more popular 'defensive' view of self-deception - that we deceive ourselves to protect against attacks to our happiness and contentment from the (sometimes painful) truth of our surroundings (p. 54). This is a convincing claim, and establishes the foundation for a theory of deception - which will hopefully provide the impetus for much-needed empirical work in this area.

Building an evolutionary theory of deception necessitates not only examples of self-deception - which seem to run deep in our evolutionary waters, as evidenced by the extensive deceit and self-deception involved in cuckoo hatchling care by self-deceived foster parents and overconfident chimpanzee warfare - but a compelling case for selection for such a costly enterprise. Trivers' case for why evolution should favor deceit and selfdeception is two-fold: first, deception is unconscious, and second, deception is bounded. These two points are important to keep in mind as Trivers explores examples of deception in our lives: the lies we tell to our partner (s), the lies we tell to ourselves about our abilities (which, when overestimated can lead to losses on the stock market or catastrophes such as plane crashes and war), and our histories (which cleverly disguise the blemishes of our past so that derogation, discrimination, and even genocide can continue to be perpetuated to further personal and political gain). Indeed, our talent for hiding the truth from ourselves - designed to provide social benefits, specifically the ability to exploit others with conflicting goals - can make us quite socially vulnerable: if we are found out, 'Your entire environment may be oriented against you, all with superior knowledge, while you peer out, ignorant and hobbled by selfdeception' (p. 176). In sum, selection for deception must involve advantages that outweigh, or circumvent, the 
social and personal (for example, suppressed immune function, negative affect) costs.

Trivers suggests that circumventing (some of) these costs is indeed possible, given the unconscious quality of our deception. Many of the costs associated with deception - from being discovered as a liar by those around you to the personal immunological costs of suppressing some known truth - imply conscious awareness of the truth and the lie. However,

'The bias occurs right away. People simply do not attend to the negative information, do not look at it, and do not remember it. Thus, the possible negative immune effects of affect suppression do not need to arise. This must be a general rule - the earlier during information processing that self-deception occurs, the less its negative downstream immunological effects'. (p. 134)

If, as Trivers contends, our deception occurs early enough that conflicting information from the outside world can simply be ignored, we can successfully sidestep many of the negative consequences mentioned above.

Further, some of these negative consequences are protected against given the bounded quality of our deception. To understand this point, Trivers uses an example of the popular connotation of 'narcissist'. The narcissist does not welcome being named so this name suggests that their self-deception is so widespread that it is no longer an advantage to them (p. 18). Alternatively, Trivers suggests that our systems of self-deception run alongside truth-storing mechanisms (p. 28). Although we may not be consciously aware of the whole truth that it might be more advantageous to ignore (perhaps that we are not, as we believe, better-than-average professionals, lovers, and fighters), this information is not completely unavailable to us. Trivers describes this bounded quality with the following empirical finding,

'When people are shown a full array of photos of themselves, from 50 percent more attractive to 50 percent less attractive, they choose the 20 percent better-looking photo as the one they like the most and think they most resemble. This is an important, general result: self-deception is bounded - 30 percent better-looking is implausible, while 10 percent better fails to gain the full advantage'. (p. 16)

In The Folly of Fools: The Logic of Deceit and SelfDeception in Human Life, Trivers has demonstrated his continued ability to further the fields of evolutionary biology, psychology, and anthropology (among others), by reaching just beyond what anecdote and empirical evidence suggests to establish an evolutionary theory of deceit and self-deception. It is likely that this theory, much like his theory of parental investment (Trivers 1972), can inform our empirical investigations of the individual acting in a social context where, often, his/her own goals are not compatible with the goals or interests of others.

\section{Competing interests}

The authors declare that they have no competing interests.

\section{Authors' contributions}

Both authors read and approved the final manuscript.

Received: 30 August 2013 Accepted: 20 October 2013

Published: 18 Nov 2013

\section{References}

Trivers, RL. (1972). Parental investment and sexual selection. In B Campbell (Ed.), Sexual Selection and the Descent of Man, 1871-1971 (pp. 136-179). Chicago: Aldine-Atherton.

\subsection{6/1936-6434-6-31}

Cite this article as: Adair and Dillon: A ladder of lies: the adaptive advantages of deception. Evolution: Education and Outreach 2013, 6:31

\section{Submit your manuscript to a SpringerOpen ${ }^{\circ}$ journal and benefit from:}

- Convenient online submission

Rigorous peer review

- Immediate publication on acceptance

- Open access: articles freely available online

- High visibility within the field

- Retaining the copyright to your article

Submit your next manuscript at springeropen.com 